\title{
Analisis Waktu Lampu Hijau, Kapasitas Kendaaran dan Derajat Jenuh di Simpang Empat Bersinyal
}

\author{
Ana Komari ${ }^{* 1}$, Heribertus Budi Santoso ${ }^{2}$, Afiff Yudha Tripariyanto ${ }^{3}$ \\ 1,2,3 Program StudiTeknik Industri, FakultasTeknik, Universitas Kadiri \\ Email: ana@unik-kediri.ac.id ${ }^{1}$, heribertus@unik-kediri.ac.id ${ }^{2}$, afiff@ unik-kediri.ac.id ${ }^{3}$
}

\section{Informasi Artikel \\ Riwayat Artikel : \\ Received : 3 - Oktober - 2019 \\ Revised : 15 - Oktober - 2019 \\ Accepted : 29 - Oktober - 2019}

Kata kunci :

Congestion

Degree of Saturation

Vehicle Capacity

Webster

\begin{abstract}
A b stract
Congestion has a negative impact on motorists during certain hours. Therefore it is necessary to do an analysis related to traffic with the aim to find out the optimum time of green light, vehicle capacity and degree of saturation. Observations were carried out in the collection of data related to the cycle time of green light, yellow light and red light. Data was collected for 60 minutes at an intersection on Jalan Veteran (east), Jalan Veteran (west), Jalan Kawi and Jalan Penanggungan, Kota Kediri, using the Webster method. Data is processed in terms of saturation flow, traffic flow rate, lost time, optimum cycle time, effective green time, total effective green time, green light time for each phase, actual green time, capacity of each crossing arm and degree of saturation. The results of the study are in accordance with the objectives of the actual green time on the Veteran Road from the east by 10 seconds with a capacity of 389 (kend / hour), degree of saturation 0.93, Veteran Road from the west by 11 seconds with a capacity of 357 (vehicle / hour), saturation degree 1,07, Jalan Kawi from the north for 8 seconds, with a capacity of 260 (kend / hour), saturation degree 1.21 and a Penanggungan from the south for 11 seconds, with a capacity of 357 (kend / hour), saturation degree 1.12 .
\end{abstract}

Untuk melakukan sitasi pada penelitian ini dengan format : R. Kayori and T. Sendow, "Kejenuhan Akibat Pengaruh Kecepatan Kendaraan Pada Jalan Perkotaan Di Kawasan Komersil (Studi Kasus: Di Segmen Jalan Depan," J. Sipil ..., vol. 1, no. 9, pp. 608-615, 2013.

\begin{abstract}
A bstrak
Kemacetan menimbulkan dampak negatif bagi pengendara kendaraan di jam - jam tertentu. Oleh karena itu perlu dilakukan analisis terkait lalu lintas dengan tujuan untuk mengetahui waktu optimum lampu hijau, kapasitas kendaraan dan derajat jenuh. Dilakukan observasi yaitu pengambilan data terkait siklus waktu lampu hijau, lampu kuning dan lampu merah. Dilakukan pengambilan data selama 60 menit di persimpangan pada Jalan Veteran (timur), Jalan Veteran (barat), Jalan Kawi dan Jalan Penanggungan, Kota Kediri, menggunkan metode Webster. Data diolah terkait arus jenuh, tingkat arus lalu lintas, waktu hilang, waktu siklus optimum, waktu hijau efektif, waktu hijau efektif tiap lengan persimpangan dan derajat jenuh. Hasil penelitian sesuai
\end{abstract}


total, waktu lampu hijau tiap fase, waktu hijau aktual, kapasitas dengan tujuan yaitu waktu 10 hijau aktual yang pada Jalan Veteran dari arah timur sebesar detik dengan kapasitas 389 (kend/jam), derajat jenuh 0,93, Jalan Veteran dari arah barat sebesar 11 detik dengan kapasitas 357 (kend/jam), derajat jenuh 1,07, Jalan Kawi dari arah utara sebesar 8 detik, dengan kapasitas 260 (kend/jam), derajat jenuh 1,21 dan Penanggungan dari arah selatan sebesar 11 detik, dengan kapasitas 357 (kend/jam), derajat jenuh 1,12.

\section{Pendahuluan}

Masalah yang sering dihadapi oleh pengguna jalan yaitu terjadinya kemacetan pada waktu tertentu. Kemacetan tersebut sudah menjadi ciri dari kota - kota yang padat penduduk. Setiap persimpangan jalan sudah disediakan rambu - rambu lalu lintas yang bertujuan untuk mengatur pergerakan dari kendaraan yang melewati jalan tersebut agar bergerak secara berurutan di setiap alur yang sudah ditentukan [1],[2],[3]. Masalah yang timbul dari adanya pengaturan lalu lintas yaitu waktu siklus yang dibutuhkan lampu merah untuk berhenti adalah lebih lama dari pada lampu hijau [4],[5],[6]. Oleh karena itu, ketika terjadi nyala lampu hijau kendaraan yang sedang melewati jalan tersebut akan terburu - buru, tetapi kendaraan didepan masih menunggu kendaraan yang berada didepannya lagi. Selain hal tersebut, ketika terjadi waktu siklus lampu merah yang lama, kendaraan akan berantrean sangat panjang dibelakang rambu - rambu lalu lintas. Pada akhirnya pengguna jalan merasa kehilangan waktunya dikarenakan beban waktu siklus pada lampu warna merah terlalu lama. Setelah merasa kehilangan waktu karena menunggu lampu hijau, pada ketika waktu lampu hijau tiba, pengguna jalan akan terburu - buru dan saling menyalip [7],[8]. Hal inilah yang membuat kemacetan ketika setelah lampu hijau selesai, tetapi masih ada pengguna jalan yang tetap berusaha melewati lampu warna merah.

Persimpangan Jalan Veteran, Jalan Kawi dan Jalan Penanggungan adalah salah satu persimpangan yang padat pengguna jalan terutama pada waktu jam berangkat kerja dan jam pulang bekerja. Padatnya lalu lintas, dikarenakan banyak area sekolah mulai dari Sekolah Menengan Pertama (SMP), Sekolah Menengah Atas (SMA), Sekolah Menengah Kejuruan (SMK) dan tempat - tempat yang berpotensi menimbulkan kemacetan. Pada gambaran tentang persimpangan lalu lintas memiliki bentuk yaitu [9],[10]:

a. Simpang berbentuk bundaran

b. Simpang berbentuk 4 lengan

c. Simpang berbentuk T

Sedang jika ditinjau dari jenisnya, dibagi menjadi dua antara lain :

a. Simpang tanpa sinyal

Simpang yang tidak ada rambu - rambu lalu lintas. Oleh karena itu, pengguna jalan harus berhati - hati dan berhenti terlebih dahulu sebelum melewatinya.

b. Simpang bersinyal

Simpang yang memiliki rambu - rambu lalu lintas sehingga pengguna jalan hanya bisa melewati ketika lampu menyala hijau pada lengan simpangnya [11], [12]. 
Didalam alat yang digunakan untuk memberikan isyarat lalu lintas memiliki fungsi untuk mengurangi konflik - konflik yang terjadi pada persimpangan dengan cara melakukan pemberhentian pada beberapa pada pergerakan arus lalu lintas, agar pengguna jalan pada persimpangan dapat bergiliran sesuai dengan nyala lampu pada rambu - rambu lalu lintas. Terkait hal itu, jenis sistem pada sinyal lalu lintas yaitu :

a. Fixed time

Pada jenis sinyal fixed time digunakan untuk rambu - rambu lalu lintas dengan asumsi waktu siklus yang tetap sesuai dengan pengaturan awal pemasangan dan jika terjadi perubahan waktu siklus dapat diatur sesuai periodenya, bisa mingguan atau pada jam - jam sibuk pengguna jalan [13].

b. Traffic responsive

Pada traffic responsive berkaitan dengan operasi waktu siklus yang berubah - ubah sesuai kondisi arus lalu lintas [14],[8].

Pada karakteristik volume lalu lintas ada jumlah gerakan yang dihitung berdasarkan pengguna jalan baik itu yang lewat adalah mobil, motor maupun truck dalam kelompok campuran maupun khusus satu jenis kendaraan. Terkait dengan metode Webster digunakan untuk menentukan waktu penyalaan lampu lalu lintas. Pada penelitian yang dilakukan sebelumnya oleh [6], didapatkan hasil waktu siklus optimum sebesar 182 detik dengan asumsi telah terjadi pengurangan sebesar 8\% dipersimpangan Iskandar Muda, oleh karena itu diperlukan penambahan waktu pada lampu hijau disetiap kaki persimpangan yang bercolume tinggi. Sedangkan pada penentuan waktu siklus lalu lintas di fase pertama berada di Jalan Jamin Ginting, kemudian fase kedua berada di Jalan Iskandar Muda dan fase ketiga berada di Jalan K.H. Wahid Hasyim.

Pada penelitian ini memiliki tujuan untuk mengetahui waktu optimum lampu hijau, kapasitas persimpangan jalan dan derajat jenuh di persimpangan pada Jalan Veteran (timur), Jalan Veteran (barat), Jalan Kawi dan Jalan Penanggungan.

\section{Tinjauan Pustaka}

\subsection{Kinerja Simpang Bersinyal}

Analisis Kinerja Simpang Bersinyal Menurut Manual Kapasitas Jalan Indonesia (1997) [15]

a) Arus Jenuh Dasar Arus jenuh dasar (S0) yaitu besarnya keberangkatan antrian dalam pendekat selama kondisi ideal (smp/jam hijau). S0 $=600 \times$ We smp/jam hijau

b) Arus Jenuh Arus jenuh yang disesuaikan (S) yaitu besarnya keberangkatan antrian dalam pendekat selama kondisi tertentu setelah disesuaikan dengan kondisi persimpangan (smp/jam hijau).

$\mathrm{S}=\mathrm{S} 0 \times \mathrm{FCS} \times \mathrm{FSF} \times \mathrm{FG} \times \mathrm{FP} \times \mathrm{FRT} \times \mathrm{FLT}$

Dimana :

F $\quad=$ Faktor penyesuaian ukuran kota

$\mathrm{FSF}_{\mathrm{SF}} \quad=$ Faktor penyesuaian untuk tipe lingkungan jalan, hambatan samping dan kendaraan tak bermotor

$\mathrm{F}_{\mathrm{G}} \quad=$ Faktor penyesuaian kelandaian 
$\begin{array}{ll}\mathrm{F}_{\mathrm{P}} & =\text { Faktor penyesuaian parkir } \\ \mathrm{F}_{\mathrm{LT}} & =\text { Faktor penyesuaian belok kiri } \\ \mathrm{F}_{\mathrm{RT}} & =\text { Faktor penyesuaian belok kanan }\end{array}$

Persimpangan adalah simpul pada jaringan jalan di mana jalan-jalan bertemu dan lintasan kendaraan berpotongan. Lalu lintas pada masing-masing kaki persimpangan bergerak secara bersama-sama dengan lalu lintas lainnya. Persimpangan jalan adalah daerah atau tempat dimana dua atau lebih jalan raya yang berpencar, bergabung, bersilangan dan berpotongan, termasuk fasilitas jalan dan sisi jalan untuk pergerakan lalu lintas pada daerah itu. Fungsi operasional utama dari persimpangan adalah untuk menyediakan perpindahan atau perubahan arah perjalanan. Persimpangan merupakan bagian penting dari jalan raya karena sebagian besar dari efisiensi, keamanan, kecepatan, biaya operasional dan kapasitas lalu lintas tergantung pada perencanaan persimpangan. Masalah masalah yang terkait pada persimpangan adalah:

a. Volume dan kapasitas (secara langsung mempengaruhi hambatan)

b. Desain geometrik dan kebebasan pandangan.

c. Perilaku lalu lintas dan panjang antrian.

d. Kecepatan.

e. Pengaturan lampu jalan.

f. Kecelakaan dan keselamatan

g. Parkir.

Persimpangan dapat dibagi atas 2 (dua) jenis yaitu [16] :

a. Persimpangan sebidang (At Grade Intersection) Yaitu pertemuan dua atau lebih jalan raya dalam satu bidang yang mempunyai elevasi yang sama. Desain persimpangan ini berbentuk huruf $\mathrm{T}$, huruf $\mathrm{Y}$, persimpangan empat kaki, serta persimpangan berkaki banyak.

b. Persimpangan tak sebidang (Grade Separated Intersection) Yaitu suatu persimpangan dimana jalan yang satu dengan jalan yang lainnya tidak saling bertemu dalam satu bidang dan mempunyai beda tinggi antara keduanya.

\section{Metode Penelitian}

Penelitian ini dilakukan pada persimpangan empat jalan Veteran, Kota Kediri dengan tahapan pengumpulan data sebagai berikut :

3.1. Data volume lalu lintas pada 1 Juli 2019 pukul 06.30 WIB -07.30 WIB

Tabel 1 Volume kendaraan

\begin{tabular}{|c|l|l|l|l|l|l|l|l|l|}
\hline & \multicolumn{9}{|c|}{ Simpang } \\
\cline { 2 - 11 } & $\begin{array}{c}\text { Jalan Veteran } \\
\text { (Timur) }\end{array}$ & $\begin{array}{c}\text { Jalan Veteran } \\
\text { (Barat) }\end{array}$ & \multicolumn{2}{c|}{$\begin{array}{c}\text { Jalan Kawi } \\
\text { (Utara) }\end{array}$} & $\begin{array}{c}\text { Jalan } \\
\text { Penanggungan } \\
\text { (Selatan) }\end{array}$ \\
\cline { 2 - 12 } Waktu & Mobil & Motor & Mobil & Motor & Mobil & Motor & Mobil & Motor \\
\hline $6: 30: 00$ & $6: 32: 00$ & 6 & 15 & 5 & 9 & 8 & 11 & 3 & 10 \\
\hline $6: 32: 00$ & $6: 34: 00$ & 3 & 6 & 2 & 10 & 5 & 14 & 2 & 6 \\
\hline $6: 34: 00$ & $6: 36: 00$ & 2 & 10 & 2 & 9 & 4 & 6 & 4 & 6 \\
\hline
\end{tabular}




\begin{tabular}{|r|l|l|l|l|l|l|l|l|l|} 
6:36:00 & $6: 38: 00$ & 6 & 12 & 5 & 11 & 2 & 9 & 5 & 16 \\
\hline $6: 38: 00$ & $6: 40: 00$ & 2 & 6 & 2 & 12 & 5 & 6 & 2 & 6 \\
\hline $6: 40: 00$ & $6: 42: 00$ & 2 & 8 & 6 & 6 & 2 & 6 & 6 & 15 \\
\hline $6: 42: 00$ & $6: 44: 00$ & 4 & 6 & 2 & 13 & 9 & 9 & 8 & 6 \\
\hline $6: 44: 00$ & $6: 46: 00$ & 2 & 14 & 6 & 6 & 2 & 6 & 5 & 13 \\
\hline $6: 46: 00$ & $6: 48: 00$ & 7 & 6 & 2 & 9 & 4 & 8 & 8 & 11 \\
\hline $6: 48: 00$ & $6: 50: 00$ & 2 & 6 & 0 & 10 & 8 & 6 & 2 & 6 \\
\hline $6: 50: 00$ & $6: 52: 00$ & 2 & 7 & 2 & 6 & 2 & 6 & 8 & 11 \\
\hline $6: 52: 00$ & $6: 54: 00$ & 8 & 12 & 2 & 11 & 2 & 8 & 5 & 6 \\
\hline $6: 54: 00$ & $6: 56: 00$ & 2 & 6 & 0 & 14 & 9 & 6 & 2 & 12 \\
\hline $6: 56: 00$ & $6: 58: 00$ & 2 & 14 & 2 & 6 & 2 & 6 & 2 & 6 \\
\hline $6: 58: 00$ & $7: 00: 00$ & 0 & 6 & 2 & 6 & 7 & 15 & 2 & 6 \\
\hline $7: 00: 00$ & $7: 02: 00$ & 2 & 15 & 0 & 11 & 2 & 6 & 1 & 9 \\
\hline $7: 02: 00$ & $7: 04: 00$ & 2 & 14 & 2 & 6 & 1 & 6 & 5 & 6 \\
\hline $7: 04: 00$ & $7: 06: 00$ & 0 & 12 & 2 & 6 & 2 & 6 & 2 & 9 \\
\hline $7: 06: 00$ & $7: 08: 00$ & 2 & 13 & 1 & 10 & 0 & 14 & 12 & 15 \\
\hline $7: 08: 00$ & $7: 10: 00$ & 2 & 12 & 2 & 9 & 2 & 6 & 2 & 9 \\
\hline $7: 10: 00$ & $7: 12: 00$ & 0 & 14 & 6 & 0 & 2 & 6 & 9 & 6 \\
\hline $7: 12: 00$ & $7: 14: 00$ & 2 & 6 & 24 & 6 & 0 & 13 & 2 & 20 \\
\hline $7: 14: 00$ & $7: 16: 00$ & 2 & 12 & 5 & 10 & 2 & 6 & 9 & 6 \\
\hline $7: 16: 00$ & $7: 18: 00$ & 0 & 6 & 2 & 12 & 2 & 0 & 2 & 10 \\
\hline $7: 18: 00$ & $7: 20: 00$ & 1 & 14 & 4 & 9 & 0 & 6 & 6 & 6 \\
\hline $7: 20: 00$ & $7: 22: 00$ & 2 & 6 & 16 & 14 & 2 & 0 & 5 & 12 \\
\hline $7: 22: 00$ & $7: 24: 00$ & 5 & 10 & 2 & 6 & 2 & 0 & 2 & 6 \\
\hline $7: 24: 00$ & $7: 26: 00$ & 2 & 2 & 6 & 9 & 0 & 6 & 0 & 8 \\
\hline $7: 26: 00$ & $7: 28: 00$ & 1 & 6 & 5 & 17 & 2 & 6 & 2 & 10 \\
\hline $7: 28: 00$ & $7: 30: 00$ & 2 & 12 & 0 & 3 & 7 & 13 & 3 & 6 \\
\hline Jumlah & 75 & 288 & 117 & 266 & 97 & 216 & 126 & 274 \\
\hline Jumlah & & 363 & & 383 & & 313 & & 400 \\
\hline Total Arus & & & 746 & & & & 713 & \\
\hline
\end{tabular}

\subsection{Gambar persimpangan empat Jl. Veteran, Kota Kediri}

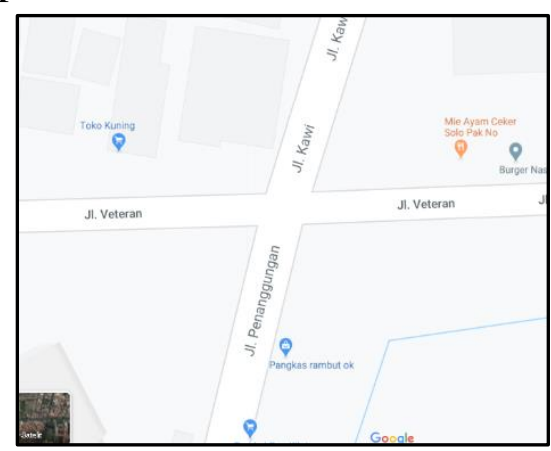

Gambar 1 Gambar simpang empat 
3.3. Populasi dan Sampel Penelitian [17],[18]

a. Populasi : seluruh pengguna jalan yang melewati persimpangan

b. Sampel : pengguna jalan yang melewati persimpangan pada periode pengambilan data.

3.4. Komposisi pergerakan lalu lintas sebagai berikut :

a. Light vehicle adalah kendaraan ringan roda empat (contoh : angkot, pick up, mobil pribadi)

b. Heavy vehicle adalah kendaraan memiliki roda melebihi empat.

c. Motor cycle adalah kendaraan beroda dua atau tiga seperti sepeda motor dan becak mesin.

3.5. Waktu pengambilan data

Pengambilan data dilakukan pada 1 Juli 2019 pukul 06.30 WIB sampai dengan 07.00 WIB.

Setelah didata dilakukan pengumpulan, maka langkah selanjutnya yaitu dilakukan pengolahan data dengan Metode Webster [19],[20]. Pada metode ini dilakukan tahapan sebagai berikut :

a. Menghitung arus jenuh dengan formula [21]:

$$
s=525 \times w(\mathrm{smp} / \mathrm{jam})
$$

Keterangan :

$\mathrm{S}=$ arus jenuh

$\mathrm{W}=$ lebar lajur $(\mathrm{m})$

$\mathrm{Smp} / \mathrm{jam}=$ satuan arus jenuh

Dengan catatan jika lebar jalan $>5,5 \mathrm{~m}$, gunakan rumus diatas. Sedangkan jika lebar jalan $<5,5$ m gunakan asumsi koefisien berikut :

Tabel 2 Arus jenuh lebar jalan $<5,5 \mathrm{~m}$

\begin{tabular}{|l|l|l|l|l|l|l|}
\hline Lebar jalan (m) & 3 & 3,5 & 4 & 4,5 & 5 & 5,5 \\
\hline $\begin{array}{l}\text { Arus jenus (s) } \\
(\mathrm{smp} / \mathrm{jam})\end{array}$ & 1.850 & 1.875 & 1.975 & 2.175 & 2.550 & 2.900 \\
\hline
\end{tabular}

Kemudian menghitung tingkat arus lalu lintas dengan formula [22]:

$$
y=\frac{q}{s}
$$

Keterangan :

$\mathrm{q}=$ arus kendaraan (volume kendaraan)

$\mathrm{s}=$ arus jenuh

b. Menghitung waktu hilang (L)

Perhitungan waktu hilang (L) dilakukan untuk mengetahui selisih pada nyala lampu hijau dengan gabungan lampu hijau dan kuning. Dikarenakan pada lampu kuning, banyak kendaraan yang sudah melewati rambu - rambu lalu lintas. Oleh karena itu, dilakukan perhitingan waktu hilang dengan formula [5]:

$$
L=n \cdot I+n\left(I_{p}-I_{a}\right)
$$


Keterangan :

$\mathrm{n}=$ banyaknya fase ( 4 fase)

$\mathrm{I}=$ waktu hilang tiap fase (1 detik)

Ip $=$ intergreen periode ( 4 detik)

ta = waktu kuning (3 detik)

c. Waktu siklus optimum dengan formula [6]:

$$
C_{0}=\frac{1,5 \times L+5}{1-Y}
$$

Keterangan :

$\mathrm{L}=$ Waktu hilang total per siklus

$\mathrm{Y}=$ Jumlah $\mathrm{y}=(\mathrm{q} / \mathrm{s})$ untuk tiap fase

d. Menghitung waktu lampu hijau efektif dengan formula [20]:

$$
g=\frac{y\left(C_{0}-L\right)}{Y}
$$

Keterangan :

$\mathrm{g}=$ waktu hijau efektif

$\mathrm{y}=$ Tingkat arus lalu lintas tiap persimpangan

$\mathrm{C}_{\mathrm{o}}=$ waktu siklus optimum

$\mathrm{L}=$ waktu hilang total per siklus

$\mathrm{Y}=$ jumlah y maksimum untuk semua fase

e. Menentukan waktu lampu hijau efektif total [3] :

$$
\text { Waktu }_{\text {hijau efektif total }}=C_{0}-L
$$

f. Menentukan waktu lampu hijau tiap fase dengan formula [19] :

$$
g_{1}=\frac{y_{1}}{Y} x(C-L)
$$

g. Menentukan waktu hijau aktual dengan formula [20] :

$$
k_{i}=g+I-a
$$

Keterangan :

$\mathrm{k}_{\mathrm{i}} \quad=$ waktu hijau aktual

g = = waktu hijau efektif

I $\quad=$ waktu hilang tiap fase (3 detik)

a = waktu kuning (3 detik)

h. Menentukan kapasitas tiap lengan persimpangan dengan formula [9]:

$$
C=\frac{S . g}{c}
$$

Keterangan :

$\mathrm{C}=\operatorname{kapasitas}(\mathrm{smp} / \mathrm{jam})$

$\mathrm{S} \quad=$ arus jenuh $(\mathrm{smp} / \mathrm{jam})$

$\mathrm{g} \quad=$ waktu hijau efektif (detik)

a = waktu siklus yang sudah ditentukan (detik) 
i. Menentukan derajat jenuh dengan formula [23] :

$$
D S=\frac{Q}{C}
$$

$$
\begin{aligned}
& \text { Keterangan }: \\
& \text { DS = Derajat jenuh } \\
& \mathrm{Q}=\text { Arus lalu lintas }(\mathrm{smp} / \mathrm{jam}) \\
& \mathrm{C}=\text { Kapasitas }(\mathrm{smp} / \mathrm{jam})
\end{aligned}
$$

\section{Hasil dan Pembahasan}

Pada penelitian terkait dengan optimasi waktu lampu hijau pada rambu - rambu lalu lintas di simpang empat Jalan Veteran (timur), Jalan Veteran (Barat), Jalan Kawi dan Jalan Penanggungan didapatkan hasil sebagai berikut :

4.1. Pada perhitungan untuk mengetahui arus jenuh dari empat simpang tersebut diasumsikan sesuai dengan tabel arus jenuh. Hal ini dikarenakan lebar jalan untuk berhentinya pengendara kendaraan sepeda motor dan mobil sebesar 3 meter. Oleh karena itu asumsi arus jenuh yaitu 1850 (smp/jam).

Tabel 3 Arus jenuh lebar jalan $<5,5 \mathrm{~m}$

\begin{tabular}{|l|l|l|l|l|l|l|}
\hline Lebar jalan (m) & $\mathbf{3}$ & 3,5 & 4 & 4,5 & 5 & 5,5 \\
\hline $\begin{array}{l}\text { Arus jenus (s) } \\
(\mathrm{smp} / \mathrm{jam})\end{array}$ & $\mathbf{1 . 8 5 0}$ & 1.875 & 1.975 & 2.175 & 2.550 & 2.900 \\
\hline
\end{tabular}

4.2. Untuk mengetahui tingkat arus lalu lintas pada simpang empat tersebut yaitu dengan cara membagi volume arus kendaraan dari total jumlah volume kendaraan dibagi dengan arus jenuh. Data total volume kendaraan terdapat pada tabel 2. di Metodologi Penelitian. Contoh perhitungan Tingkat arus lalu lintas pada simpang empat Jalan Veteran (Barat) menggunakan formula sebagai berikut :

$$
\begin{aligned}
& y=\frac{q}{s} \\
& y=\frac{320}{1850} \\
& y=0,169 \mathrm{smp} / \mathrm{jam}
\end{aligned}
$$

Untuk perhitungan tingkat arus lalu lintas pada simpat empat dapat dilihat pada tabel sebagai berikut :

Tabel 4 Tingkat arus lalu lintas

\begin{tabular}{|c|c|c|c|c|}
\hline Lengan Simpang & $\begin{array}{c}\text { Jalan Veteran } \\
\text { (Timur) }\end{array}$ & $\begin{array}{c}\text { Jalan Veteran } \\
\text { (Barat) }\end{array}$ & $\begin{array}{c}\text { Jalan } \\
\text { Kawi } \\
\text { (Utara) }\end{array}$ & $\begin{array}{c}\text { Jalan } \\
\text { Penanggungan } \\
\text { (Selatan) }\end{array}$ \\
\hline $\begin{array}{c}\text { q (Volume } \\
\text { Kendaraan) }\end{array}$ & 313 & 400 & 363 & 383 \\
\hline $\begin{array}{c}\text { s (Arus Jenuh) } \\
\text { (kend/jam) }\end{array}$ & 1850 & 1850 & 1850 & 1850 \\
\hline $\mathrm{y}_{1}=\mathrm{q} / \mathrm{s}$ (smp/jam) & 0,169 & 0,216 & 0,196 & 0,207 \\
\hline
\end{tabular}




\begin{tabular}{|c|c|c|}
\hline $\begin{array}{c}\text { y kritis }=\text { ytimur }+ \\
\text { ybarat dan } \text { yselatan }^{+} \\
\text {yutara }\end{array}$ & 0,385 & 0,403 \\
\hline $\begin{array}{c}\text { Y }=\text { ytimur }+ \text { ybarat }+ \\
\text { yselatan }+ \text { yutara }\end{array}$ & 0,789 \\
\hline
\end{tabular}

Pada tingkat arus lalu lintas pada q (volume kendaraan berdasarkan data yang diambil melalui observasi), sedangkan pada arus jenuh berdasarkan tabel arus jenuh dikarenakan lebar jalan tempat berhenti kendaraan memiliki asumsi lebar 3 meter. Untuk tingkat arus lalu lintas pada Jalan Veteran (timur) sebesar 0,169 (smp/jam), pada Jalan Veteran (barat) sebesar 0,216 (smp/jam), jalan Kawi (utara) sebesar 0,196 (smp/jam) dan pada Jalan Penanggungan (selatan) sebesar 0,207 (smp/jam). Untuk nilai kritis pada Jalan Veteran (timur) dengan Jalan Veteran (barat) sebesar 0,385 (smp/jam), berbeda dengan nilai kritis pada Jalan Kawi (utara) dengan Jalan Penanggungan (selatan) sebesar 0,403 lebih besar. Berdasarkan tingkat arus lalu lintas tersebut didapatkan nilai $\mathrm{Y}$ maksimum pada dua jalur kritis tersebut sebesar 0,789 (smp/jam).

4.3. Untuk mengetahui waktu hilang diketahui warna kuning memiliki waktu sebesar 3 detik, sedangkan pada waktu hilang tiap fase sebesar 1 detik. Untuk nilai pada intergreen peride sebesar 4 detik. Menggunakan formula sebagai berikut :

$$
\begin{aligned}
& L=n . I+n\left(I_{p}-I_{a}\right) \\
& L=4.1+4(4-3) \\
& L=8 \text { detik }
\end{aligned}
$$

Didapatkan hasil perhitungan waktu hilang sebesar 8 detik pada tiap fase yang berjumlah 4 fase. Kehilangan waktu tersebut terjadi karena pengendara menerabas lampu warna kuning, yang seharusnya belum boleh melakukan perjalanan di rambu lalu lintas tersebut.

4.4. Dalam perhitungan siklus waktu optimal digunakan formula :

$$
\begin{aligned}
C_{0} & =\frac{1,5 \times L+5}{1-Y} \\
C_{0} & =\frac{1,5 \times 8+5}{1-0,789} \\
C_{0} & =56,7 \text { detik dibulatkan } 57 \text { detik }
\end{aligned}
$$

Pada siklus waktu optimal sebesar 57 detik tiap siklus yang terjadi pada satu kali putaran di simpang empat.

4.5. Pada perhitungan waktu lampu hijau efektif total dengan formula :

$$
\begin{aligned}
& \text { Waktu }_{\text {hijau efektif total }}=C_{0}-L \\
& \text { Waktu }_{\text {hijau efektif total }}=57-8 \\
& \text { Waktu }_{\text {hijau efektif total }}=49 \text { detik }
\end{aligned}
$$

Pada perhitungan waktu lampu hijau efektif dengan totak 49 detik pada empat fase tersebut. 
4.6. Pada perhitungan waktu lampu hijau tiap fase yaitu dengan contoh pada Jalan Veteran menggunakan formula sebagai berikut :

$$
\begin{aligned}
& g_{1}=\frac{y_{1}}{Y} x(C-L) \\
& g_{1}=\frac{0,196}{0,789} x(57-8)=12,1 \text { dibulatkan } 12 \text { detik }
\end{aligned}
$$

Untuk perhitungan pada fase berikutnya yaitu :

Tabel 5 Rekapitulasi perhitungan waktu lampu hijau efektif

\begin{tabular}{|c|c|c|c|c|}
\hline Lengan Simpang & $\begin{array}{c}\text { Jalan Veteran } \\
\text { (Timur) }\end{array}$ & $\begin{array}{c}\text { Jalan Veteran } \\
\text { (Barat) }\end{array}$ & $\begin{array}{c}\text { Jalan } \\
\text { Kawi } \\
\text { (Utara) }\end{array}$ & $\begin{array}{c}\text { Jalan } \\
\text { Penanggungan } \\
\text { (Selatan) }\end{array}$ \\
\hline $\begin{array}{c}\text { Waktu hijau efektif } \\
\text { (detik) }\end{array}$ & 12 & 13 & 10 & 13 \\
\hline
\end{tabular}

4.7. Setelah diketahu waktu lampu hijau efektif pada tiap fasenya, dilakukan perhitungan waktu lampu hijau aktual menggunakan formula :

$$
\begin{aligned}
& k_{i}=g+I-a \\
& k_{-1}=12+1-3=10 \text { detik }
\end{aligned}
$$

Pada fase 1 yaitu Jalan Veteran (timur) memiliki waktu aktual sebesar 10 detik, untuk fase selanjutnya dapat dilihat pada rekapitulasi tabel berikut :

Tabel 6 Rekapitulasi perhitungan waktu aktual lampu hijau

\begin{tabular}{|c|c|c|c|c|}
\hline Lengan Simpang & $\begin{array}{c}\text { Jalan Veteran } \\
\text { (Timur) }\end{array}$ & $\begin{array}{c}\text { Jalan Veteran } \\
\text { (Barat) }\end{array}$ & $\begin{array}{c}\text { Jalan } \\
\text { Kawi } \\
\text { (Utara) }\end{array}$ & $\begin{array}{c}\text { Jalan } \\
\text { Penanggungan } \\
\text { (Selatan) }\end{array}$ \\
\hline $\begin{array}{c}\text { Waktu hijau aktual } \\
\text { (detik) }\end{array}$ & 10 & 11 & 8 & 11 \\
\hline
\end{tabular}

Dari rekapitulasi perhitungan waktu aktual, pada Jalan Kawi memiliki waktu aktual terkecil dikarenakan banyak pengendara lebih memilih menerobos lampu warna kuning, sebelum warna hijau menyala.

4.8. Untuk mengetahui kapasitas jalan ditiap lengan persimpangan menggunakan formula :

$C=\frac{S \cdot g}{c}$

$C_{1}=\frac{1850.12}{57}=389\left(\frac{\text { kend }}{\text { jam }}\right)$

Pada perhitungan kapasitas jalan ditiap lengan pada empat persimpangan direkap pada tabel berikut : 
Tabel 7 Rekapitulasi kapasitas tiap simpangan (kend/jam)

\begin{tabular}{|c|c|c|c|c|}
\hline Lengan Simpang & $\begin{array}{c}\text { Jalan Veteran } \\
\text { (Timur) }\end{array}$ & $\begin{array}{c}\text { Jalan Veteran } \\
\text { (Barat) }\end{array}$ & $\begin{array}{c}\text { Jalan } \\
\text { Kawi } \\
\text { (Utara) }\end{array}$ & $\begin{array}{c}\text { Jalan } \\
\text { Penanggungan } \\
\text { (Selatan) }\end{array}$ \\
\hline $\begin{array}{c}\text { Kapasitas jalan } \\
\text { (kend/jam) }\end{array}$ & 389 & 356 & 260 & 357 \\
\hline
\end{tabular}

Setiap jamnya pada pukul 06.30 - 07.30 WIB, kendaraan yang lalu lalang pada simpang empat tersebut di Jalan Veteran (timur) memiliki jumlah sebesar 389 (kend/jam), pada Jalan Veteran (barat) sebesar 356 (kend/jam), sedangkan pada Jalan Kawi sebesar 260 (kend/jam) dan Jalan Penanggungan sebesar 357 (kend/jam). Dalam hal ini, kapasitas terbesar terjadi pada Jalan Penanggungan, dikarenakan area jalan tersebut banyak tempat instansi dan kantor - kantor yang memiliki radius dekat dengan simpang empat.

4.9. Setelah diketahui kapasitas jalan tiap simpang, diperlukan perhitungan derajat jenuh untuk mengetahui penentuan tingkat kinerja pada simpang dan segmen dijalanpada tiap simpang dengan contoh perhitungan Jalan Veteran (timur) menggunakan formula berikut

$$
\begin{aligned}
& D S=\frac{Q}{C} \\
& D S=\frac{363}{389}=0,93
\end{aligned}
$$

Pada perhitungan derajat jenuh ditiap simpang, pada tabel sebagai berikut :

Tabel 8 Derajat jenuh pada tiap simpang

\begin{tabular}{|c|c|c|c|c|}
\hline Lengan Simpang & $\begin{array}{c}\text { Jalan Veteran } \\
\text { (Timur) }\end{array}$ & $\begin{array}{c}\text { Jalan Veteran } \\
\text { (Barat) }\end{array}$ & $\begin{array}{c}\text { Jalan } \\
\text { Kawi } \\
\text { (Utara) }\end{array}$ & $\begin{array}{c}\text { Jalan } \\
\text { Penanggungan } \\
\text { (Selatan) }\end{array}$ \\
\hline Derajat jenuh & 0,93 & 1,07 & 1,21 & 1,12 \\
\hline
\end{tabular}

Pada derajat jenuh yang terjadi pada tiap simpang empat memiliki asumsi, jika derajat jenuh rendah berarti pada jalan tersebut terjadi lalu lalang kendaraan dengan kecepatan tinggi, sedangkan jika terjadi lalu lalang dengan kecepatan rendah berarti terjadi peningkatan derajat jenuh. Pada lengan simpang di Jalan Veteran (timur), Jalan Veteran (barat), Jalan Kawi dan Jalan Penanggungan memiliki derajat jenuh yang tinggi yaitu > 0,9 diartikan kendaraan lalu lalang dengan kecepatan tinggi.

\section{Kesimpulan}

Berdasarkan penelitian yang sudah dilakukan pengolahan dan pembahasan, dapat disimpulkan dengan beberapa kesimpulan: pada waktu hijau aktual yang didapatkan dari perhitungan menggunakan metode Webster yaitu pada Jalan Veteran dari arah timur memiliki waktu hijau aktual sebesar 10 detik, sedangkan pada Jalan Veteran dari arah barat memiliki 
waktu hijau aktual sebesar 11 detik, kemudian pada Jalan Kawi dari arah utara dengan waktu hijau aktual sebesar 8 detik dan pada Jalan Penanggungan dari arah selatan waktu hijau aktual sebesar 11 detik. Sedangkan untuk kapasitas yang dapat ditampung oleh jalan selama satu jam yaitu pada Jalan Veteran ( timur) memiliki kapasitas 389 (kend/jam), untuk Jalan Veteran (barat) memiliki kapasitas sebesar 357 (kend/jam), untuk Jalan Kawi memiliki kapasitas sebesar 260 (kend/jam) dan pada Jalan Penanggungan (selatan) memiliki kapasitas sebesar 357 (kend/jam). Dalam nilai derajat jenuh yang dihasilkan tiap persimpangan yaitu pada Jalan Veteran ( timur) sebesar 0,93, untuk Jalan Veteran (barat) sebesar 1,07, untuk Jalan Kawi sebesar 1,21 dan pada Jalan Penanggungan (selatan) memiliki derajat jenuh sebesar 1,12.

\section{Daftar Pustaka}

[1] W. Widodo, N. Wicaksono, and Harwin, "Analisis Volume, Kecepatan , dan Kepadatan Lalu Lintas dengan Metode Greenshields dan Greenberg,” J. Ilm. Semesta Tek., vol. 15, no. 2, pp. 178-184, 2012.

[2] H. Yustianingsih and Istianah, "KAJIAN KORELASI TINGKAT KEPADATAN LALU LINTAS DI KOTA SEMARANG DENGAN KONSENTRASI CO DAN Pb," Untidar, vol. 01, pp. 19-24, 2017.

[3] M. Town, P. T. Adeke, A. A. Atoo, and A. E. Zava, "Traffic Signal Design and Performance Assessment of 4-Leg Intersections Traffic Signal Design and Performance Assessment of 4-Leg Intersections Using Webster' s Model : A Case of ' SRS ' and ' BDivision'Intersections in Makurdi Town," no. August, 2018.

[4] S. J. A. Wesli, "Kajian Kebutuhan Lampu Lalu Lintas Pada Simpang 6," vol. 3, no. 2, pp. 118-127, 2016.

[5] C. Noval, I. A. Virgono, and R. E. Saputra, "Optimasi Lampu Lalu Lintas Cerdas Menggunakan Metode Webster,” e-Proeeding Eng., vol. 5, no. 3, pp. 6236-6243, 2018.

[6] C. Ulfah, "Optimasi Pengaturan Lampu Lalu Lintas Kota Medan Menggunakan Graf dan Metode Webster," Universitas Sumatera Utrara, 2018.

[7] A. Verma, G. Nagaraja, C. S. Anusha, and S. K. Mayakuntla, "Traffic Signal Timing Optimization for Heterogeneous Traffic Conditions Using Modified Webster's Delay Model," Transp. Dev. Econ., no. 2, 2018.

[8] V. Builenko, A. Pakhomova, and S. Pakhomov, "Optimization of the method for collecting source data to calculate the length of the traffic light control cycle," Transp. Res. Procedia, vol. 36, pp. 90-94, 2018, doi: 10.1016/j.trpro.2018.12.048.

[9] J. Setiabudhi et al., "Analisis Kinerja Simpang," Fak. Tek. Sipil dan Lingkungan, Inst. Teknol. Bandung, no. 1506134, pp. 1-11, 2012.

[10] A.- Desmi, L. A. Widari, and R. Yanti, "Efektifitas Model Karakteristik Arus Lalu Lintas Pada Ruas Jalan Simpang 4 Bireun (Perbandingan Dengan Metode Greenshield, Greenberg, Underwood),” Teras J., vol. 9, no. 1, p. 19, 2019, doi: 10.29103/tj.v9i1.178.

[11] E. P. Kulo, S. Y. R. Rompis, and J. A. Timboeleng, “Analisis Kinerja Simpang Tak Bersinyal Dengan Analisis Gap Accaptance Dan MKJI 1997,” J. Sipil Statik Vol.5, vol. 
5, no. 2, 2017.

[12] A. Al-Kandari, I. Al-Shaikhli, and A. Najaa, "Comparative Study between Traffic Control Methods Using Simulation Software," Int. J. Mach. Learn. Comput., vol. 3, no. 5, pp. 424-429, 2013, doi: 10.7763/ijmlc.2013.v3.353.

[13] T. Tsuboi and N. Yoshikawa, "Traffic flow analysis in Ahmedabad (India)," Case Stud. Transp. Policy, vol. 8, no. 1, pp. 215-228, 2019, doi: 10.1016/j.cstp.2019.06.001.

[14] S. Salini and R. Ashalatha, "Analysis of traffic characteristics of urban roads under the influence of roadside frictions," Case Stud. Transp. Policy, vol. 8, no. September 2016, pp. 94-100, 2018, doi: 10.1016/j.cstp.2018.06.008.

[15] Binamarga, "Manual Kapasitas Jalan Indonesia," PU-NET, 1997. https://binamarga.pu.go.id/.

[16] E. K. Morlok, Pengantar Teknik dan Perencanaan Transportasi. 1991.

[17] N. A. Sudharta, "Penentuan Populasi dan Sampel didalam Penelitian," widisudharta.weebly.com. .

[18] M. P. Dr. Whidmurni, "Penelitian Kuantitatif," Pemaparan Metod. Kuantitatif, 2017.

[19] R. Pistolese, "The Webster Technique: A chiropractic technique with obstetric implications," J. Manipulative Physiol. Ther., vol. 25, pp. E1-9, 2002, doi: 10.1067/mmt.2002.126127.

[20] B. S. R. and N. V. H. Reddy, "Signal Design for T-Intersection By Using Webster' S Method in Nandyal Town , Kurnool District of Andhra Pradesh," Int. Res. J. Eng. Technol., vol. 03, no. 04, pp. 1124-1131, 2016.

[21] I. W. Kustanrika, "PERHITUNGAN SINYAL PADA SIMPANG DENGAN METODE WEBSTER,” J. Kaji. Ilmu dan Teknol., vol. 53, no. 9, pp. 1689-1699, 2013, doi: 10.1017/CBO9781107415324.004.

[22] H. Wibisana and N. Utono, "Pemetaan Kecepatan dan Kerapatan Lalu Lintas di Ruas Jalan Arteri Kota Surabaya,” J. Tek. Sipil, vol. 12, no. 2, pp. 121-145, 2019, doi: $10.28932 /$ jts.v12i2.1420.

[23] R. Kayori and T. Sendow, "Kejenuhan Akibat Pengaruh Kecepatan Kendaraan Pada Jalan Perkotaan Di Kawasan Komersil (Studi Kasus: Di Segmen Jalan Depan,” J. Sipil ..., vol. 1, no. 9, pp. 608-615, 2013. 